\title{
High-Salt Diet and Hypertension: Focus on the Renin-Angiotensin System
}

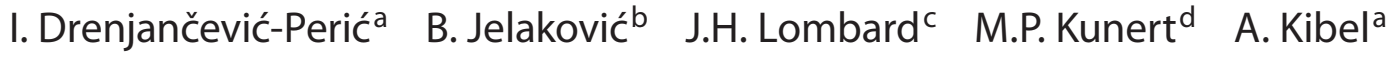 \\ M. Gros ${ }^{\text {a }}$

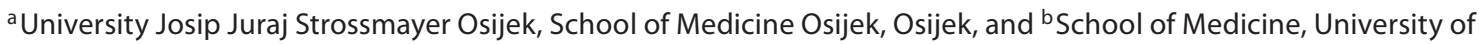 \\ Zagreb, Department of Nephrology and Arterial Hypertension, University Hospital Center Zagreb, Zagreb, Croatia; \\ ${ }^{c}$ Medical College of Wisconsin, and ${ }^{d}$ College of Nursing, University of Wisconsin, Milwaukee, Wisc., USA
}

\section{Key Words}

Hypertension · Salt · Sodium · Renin-angiotensin system

\begin{abstract}
A high-salt diet is one of the major risk factors in the development and maintenance of hypertension. Numerous experimental and observational studies have confirmed the association of sodium intake with blood pressure levels. The effects of a high-salt diet are related to the function of the renin-angiotensin system, which is normally suppressed by a high-salt diet. Endothelial dysfunction probably plays an important role in the influence of high sodium intake on blood pressure, although the exact mechanisms remain elusive. Genetic factors are known to be very important, and various consomic and congenic rat strains as animal models have proven to be very useful in bringing us a step closer to understanding the interaction between salt intake and hypertension. In this article, experimental data obtained in studies on animals and humans, as well as epidemiological data are reviewed.

Copyright $\odot 2010$ S. Karger AG, Basel
\end{abstract}

\section{Introduction}

Hypertension is defined by a systolic blood pressure that is $\geq 140 \mathrm{~mm} \mathrm{Hg}$ and a diastolic blood pressure that is $\geq 90 \mathrm{~mm} \mathrm{Hg}$ [1]. The World Health Organization ranks coronary heart disease and cerebrovascular diseases as the world's leading causes of death [2]. Globally, according to the World Health Report 2002, about $62 \%$ of cerebrovascular disease and $49 \%$ of ischemic heart disease are attributable to suboptimal blood pressure (systolic $>115$ $\mathrm{mm} \mathrm{Hg}$ ), and hypertension is estimated to cause $7.1 \mathrm{mil}-$ lion deaths, about $13 \%$ of the total [3]. For the last several decades, hypertension has been ranked as one of the top 10 leading causes of worldwide disability-adjusted life years [4]. According to the results of Kearney et al. [5], more than $25 \%$ of the world adult population (approx. 1 billion) has hypertension, and it was estimated that in $2025,29 \%$ (1.56 billion) of the adult population will be hypertensive (an increase of the total number of hypertensive individuals by 60\%). The Prospective Studies Collaboration observed a linear relationship between blood pressure levels and cardiovascular and cerebrovascular mortality [6]. The continuum between blood pressure and cardiovascular morbidity and mortality is present

Ines Drenjančević-Perić, $\mathrm{MD}, \mathrm{PhD}$

School of Medicine, University Josip Juraj Strossmayer Osijek

J. Huttlera 4

HR-31000 Osijek (Croatia)

Tel. +385 3151 2882, Fax +385 3151 2833, E-Mail idperic@ mefos.hr 
Table 1. Prevalence of hypertension in adult populations of several European countries and globally

\begin{tabular}{lll}
\hline Country & Prevalence of hypertension (year) & $\begin{array}{l}\text { Reference } \\
\text { number }\end{array}$ \\
\hline Croatia & $37.5 \%(2007)$ & 11 \\
Czech Republic & $39.1 \%(2001)$ & 21 \\
England & men 33.1\%, women 30.1\%(2003) & 13 \\
Finland & men 52.1\%, women 33.6\%(2007) & 18 \\
France & men 37.7\%, women 32.2\%(1996) & 20 \\
Germany & $55.3 \%(1998)$ & 16 \\
Italy & $37.7 \%(1998)$ & 14 \\
Poland & $29.0 \%(2002)$ & 12 \\
Romania & $36.6 \%(2005)$ & 23 \\
Spain & $45.1 \%(1998)$ & 15 \\
Sweden & $38.4 \%(1996)$ & 5 \\
Global burden & $26.4 \%(2000)$, estimate for the \\
& year 2025: 29.2\% & \\
\hline
\end{tabular}

even below the present cutoff for hypertension, as confirmed in the Framingham study [7].

At present, the worldwide prevalence of hypertension is higher than it was several decades ago [8-10]. WolfMaier et al. [8] observed differences in age-adjusted prevalence of hypertension between Northern America and developed countries in Europe (28 vs. $44 \%$ ). They have also confirmed that hypertension is more strongly correlated to cerebrovascular mortality $(r=0.79)$ than to total cardiovascular mortality $(\mathrm{r}=0.44)$, which is in line with the fact that cerebrovascular mortality in the United States and Canada is the lowest in the world (27.6/100,000 vs. 41.2/100,000 in Europe). Based on results of the Epidemiology of Arterial Hypertension in Croatia study (EHUH), overall prevalence of hypertension in Croatia is $37.5 \%$ [11], so it should not be surprising that cardiovascular morbidity in Croatia is also very high $(>54 \%$ in 2004). EHUH results are in line with reports from other European countries like Italy $37.7 \%$, Spain $45.1 \%$, England men 33.1\%, England women 30.1\%, Germany $55.3 \%$, France men $37.7 \%$, France women $32.2 \%$, Sweden $38.4 \%$ Finland men $52.1 \%$, Finland women $33.6 \%$ and Poland 29\% [12-20]. Concordance was found with countries that belong to former socialistic economies [5]: Romania 36.6\% [23], Czech Republic 39.1\% [21] and Slovakia [22]. The data is summarized in table 1 .

Dietary salt intake is a known risk factor for hypertension. Although a large number of studies have been conducted to elucidate this association, the mechanisms by which the increase in salt intake leads to development of salt-dependent hypertension are not completely under- stood. However, it is known that a high-salt diet alters the functioning of the renin-angiotensin system (RAS; discussed below).

\section{Presumed Pathophysiology of Salt-Induced Hypertension}

An explanation of the link between sodium intake and hypertension was established roughly 40 years ago by Guyton et al. [24]. They proposed that sodium balance after salt intake is regulated by the pressure-natriuresis mechanism. Sodium loading is associated with a transient increase in blood pressure which returns to primary values after pressure-natriuresis and regulation of extracellular volume (ECV). Some individuals have impairments of sodium elimination mechanisms and for the same sodium natriuresis effect they need to have higher blood pressure. Thus, sodium retention causes expansion of ECV, causing higher cardiac output with tissue perfusion that exceeds metabolic needs. Peripheral tissue vasculature responds by activating autoregulatory vasoconstriction, causing further increases in peripheral resistance $[24,25]$. All these facts, as well as studies performed on transplanted kidney patients, places the kidney in a central position in the regulation of blood pressure [26].

A later model proposed by Julius [27] aligned contradictory results in previously seen studies related to role of ECV expansion and described different phases of hypertension, with a transition from a high cardiac output (ECV expansion) and normal systemic vascular resistance early in the course of the disease to a normal cardiac output (normal ECV) and increased systemic vascular resistance at a later phase [26]. However, a number of newer studies have shown that the mechanisms involved in hypertension associated with high salt intake are much more complex and that multiple interconnected factors participate in the pathophysiology of hypertension.

High sodium concentrations may also, in addition to effects mediated by ECV expansion, have direct hypertensive actions, such as induction of cardiac myoblast and smooth muscle cell hypertrophy [28], activation of NF$\kappa \mathrm{B}$ in proximal tubular cells (leading to renal inflammation) [29], changes in the RAS, induction of oxidative stress, and others. A dysregulation of sodium metabolism can also be related to changes in genes and receptors associated with mineralocorticoid synthesis and function [26]. 


\section{Studies Confirming the Relation of Sodium Intake to High Blood Pressure}

Experimental observations by $\mathrm{Gu}$ et al. [30,31] examined whether a long-term high-salt diet causes hypertension and renal injury in normal Sprague-Dawley rats. It was demonstrated that hypertension can be induced by a prolonged high-salt diet and that it is associated with increased renal injury and significant changes in renal cytokine gene expression profiles that are closely related to the proinflammatory response, promatrix formation and endothelial dysfunction, and attenuated cell survival and differentiation [30]. They found that a high-salt diet decreases renal expression of vascular endothelial growth factor [31], whereas a subsequent study revealed that inhibition of the vascular endothelial growth factor receptor enhances dietary salt-induced hypertension [32].

A large number of epidemiologic, evolutionary and clinical studies have confirmed that salt intake is a significant factor in determining the blood pressure level, and thereby the prevalence of hypertension. Epidemiological studies indicate that blood pressure increases with age only if accompanied by increased salt intake. For example, Yanomamo Indians are still eating food which contains very low salt, i.e. less than $50 \mathrm{mmol} \mathrm{NaCl}(2.9 \mathrm{~g}$ $\mathrm{NaCl}$ ), and is very similar to the food humans have consumed over thousands of years of evolution [33, 34]. In this Neolithic tribe, as well as in many similar populations worldwide, there is no age-related rise in blood pressure, and the prevalence of hypertension is less than $5 \%$. However, an increase in blood pressure was observed when members of those populations migrated to the Westernized societies where sodium intake is severalfold higher. The impact of this change is most obvious in Aborigines and African-Americans, who have the highest prevalence of salt-sensitive hypertension $(73 \% \mathrm{com}$ pared to $51 \%$ and $26 \%$ in other hypertensive groups and normotensives, respectively) [35].

The Intersalt Study, which attempted to relate sodium intake to blood pressure from an epidemiological perspective [36], was a cross-sectional assessment of more than 10,000 subjects in 52 locations around the world. Within centers, sodium excretion was significantly related to blood pressure in individual subjects. In an initial analysis of 48 of the 52 centers in which sodium intake averaged $>100 \mathrm{mmol} / 24 \mathrm{~h}$, no significant association between sodium intake and median blood pressure was found. However, after inclusion of the remaining 4 centers, in which the average sodium consumption was
$0.2-50 \mathrm{mmol} / 24 \mathrm{~h}$, a significant association of sodium to blood pressure was revealed [36].

The lowering of dietary sodium has been demonstrated to cause a decrease in blood pressure, as evident from multiple trials [37]. Kempner's rice diet from 1948 was efficient in lowering blood pressure in malignant hypertension [38]. Dose-related effects of salt reduction on blood pressure values were shown in the DASH study [39], and results from NHANES I revealed that a difference of 100 $\mathrm{mmol}$ of $\mathrm{NaCl}$ is related to a $32 \%$ decrease of cerebrovascular risk [40,41]. The valuable effect of salt reduction in elderly subjects, where isolated systolic hypertension is the most prevalent, was observed in the Trial of Nonpharmacological Intervention in the Elderly (TONE) [42]. A decrease of $40 \mathrm{mmol}$ of salt was related to a decrease of systolic/diastolic blood pressure by $4.3 / 2.0 \mathrm{~mm} \mathrm{Hg}$. Evaluations of a 'no added salt diet' on a hypertensive population with high dietary sodium intake (and not on any drug therapy for hypertension) revealed beneficial effects. 24-hour Holter monitoring of blood pressure and 24-hour urinary sodium excretion were measured before and after 6 weeks of the 'no added salt diet'. Despite a modest effect on dietary sodium restriction, the 'no added salt diet' significantly decreased systolic and diastolic blood pressure [43]. Randomized controlled trials in patients with hypertension [44] suggest that reducing sodium intake by $80-100 \mathrm{mmol}$ per day (equaling a reduction of 4.7-5.8 g salt/day) from an initial intake of around $180 \mathrm{mmol}$ per day reduces blood pressure by an average of 4-6 mm Hg [1,37, 45-48], although with large variability among patients. Jürgens and Graudal [49] reviewed 57 trials, mainly in Caucasians, to study the influence of sodium intake levels on blood pressure and concluded that reduced sodium intake in Caucasians with elevated blood pressure has a useful effect to reduce blood pressure in the short term. The results suggest that the effect of low versus high sodium intake on blood pressure was greater in Black and Asian patients than in Caucasians [49]. Finally, subjects enrolled in TOHP-I and TOHP-II who had reduced salt intake (net decrease in sodium excretion was 44 and $33 \mathrm{mmol} / 24 \mathrm{~h}$, respectively) had $25 \%$ less cardiovascular death and $20 \%$ less total death after 15 years of follow-up [50].

\section{Alterations in Functioning of the RAS}

The RAS is a major homeostatic system that controls body fluid volume, electrolyte balance, blood pressure, and neuronal and endocrine functions related to cardio- 
vascular control. The RAS is a key factor in many cases of essential hypertension, as indicated by the successful treatment of high blood pressure with angiotensin-converting enzyme (ACE) inhibitors and angiotensin II receptor blockers. The RAS exhibits its effects through the effector molecule angiotensin II, which binds to specific membrane-bound angiotensin receptors located in multiple tissues, including the vasculature [51, 52]. Renin is the rate-limiting enzyme in angiotensin II formation [53]. Renin is an aspartyl protease that is synthesized and released by juxtaglomerular cells located in the afferent and efferent arterioles of the renal glomerulus in response to a variety of stimuli, including decreased renal perfusion pressure [54], increased activity of renal sympathetic nerves and decreased $\mathrm{NaCl}$ delivery to the macula densa of the juxtaglomerular apparatus [24]. Renin cleaves angiotensinogen, a glycoprotein consisting of 429 amino acids (MW $=53-57 \mathrm{kDa}$ ) which is synthesized by hepatocytes [55], to the decapeptide angiotensin I [56], which is further processed by ACE to angiotensin II, a potent vasoactive octapeptide. Angiotensin II can also be formed via non-ACE pathways, such as chymase, which can lead to a phenomenon called 'angiotensin escape' in some patients treated with ACE inhibitors. In these cases, circulating concentrations of angiotensin II can return to normal despite continuing therapy with ACE inhibitors (hence 'escape'), illustrating the importance of alternative non-ACE angiotensin II-forming pathways [57]. Angiotensin II exerts its effects through activation of angiotensin II type $1\left(\mathrm{AT}_{1}\right)$ and angiotensin II type $2\left(\mathrm{AT}_{2}\right)$ receptors, with the latter generally assumed to counteract the vasoconstrictor and growth-stimulatory actions of $\mathrm{AT}_{1}$ receptors [58]. There are several biologically active angiotensin metabolites, including angiotensin III, angiotensin IV and angiotensin-(1-7), which stimulate the 2 receptors mentioned above (but with low affinity), and/ or newly discovered putative receptors [58, 59]. Angiotensin III is formed from angiotensin II by aminopeptidase $\mathrm{A}$ and angiotensin IV is formed from angiotensin II by aminopeptidase $\mathrm{N}$, whereas angiotensin-(1-7) is formed from angiotensin I by neutral endopeptidase or prolyl endopeptidase and from angiotensin II by prolyl endopeptidase, prolyl carboxypeptidase or ACE $2[58,60]$. The biological relevance of the different metabolites in various tissues is still under investigation.

Salt-sensitive hypertension is generally associated with some form of impaired renal function, which results in an impaired ability of the individual to properly excrete sodium and water. A high-salt diet normally suppresses angiotensin II level trough physiological blood pressure level control mechanisms. In $40-50 \%$ of the essential hypertensive population, adrenal and renal vascular responses to angiotensin II do not exhibit the expected changes predicted by changes in sodium intake. These individuals have been called nonmodulators [61]. 'Salt sensitivity' is manifested as a large blood pressure change in response to an acute or chronic salt intake change, and is defined as the tendency for blood pressure to fall during salt reduction and rise during salt repletion [62]. If the difference in blood pressure between a salt-loaded state (after administration of 2 liters of saline) and a salt-depleted state (low-sodium diet, about $10 \mathrm{mmol} /$ day of $\mathrm{Na}$ plus oral furosemide) is $\geq 10 \mathrm{~mm} \mathrm{Hg}$, it can be defined as salt sensitivity, whereas a difference of $\leq 5 \mathrm{~mm} \mathrm{Hg}$ can be defined as salt resistance [26]. Using this definition, salt sensitivity has been reported in certain segments of the population where $26 \%$ of normotensive subjects and $51 \%$ of hypertensive subjects could be classified as salt-sensitive [63]. It is determined by many factors, such as genetic constitution, race/ethnicity, age, body mass, overall diet quality and associated disease states [62]. Salt sensitivity has been reported among people with renal disease, diabetes, obesity, hypertension and old age [35, 64].

Recent studies have demonstrated several structural alterations of genes encoding the components of the RAS that are related to the development of essential hypertension in humans and in animal models of hypertension. Haplotype analysis in humans by Hasimu et al. [65] revealed a significantly different haplotype distribution between normotensive individuals and subjects with essential hypertension in regard to the renin gene. Elevated plasma renin activity levels with a missense mutation in exon 9 of the renin gene were associated with a specific G/G genotype and hypertension, suggesting that the mutation in exon 9 may affect the enzymatic function of renin by increasing its activity, and consequently may be involved in the etiology of hypertension [65]. A genetic association study in the human population by Giner et al. [66] and Poch et al. [67] evaluated the association between salt-sensitive hypertension and genetic polymorphisms of the RAS in humans. Their study demonstrated a significant association between the insertion/deletion (I/D) polymorphism of the ACE gene and salt-sensitive hypertension. Additionally, salt-sensitive patients exhibited higher blood pressure and less plasma renin activity suppression in response to elevated sodium intake. This was associated with a particular 11b-hydroxysteroid dehydrogenase type 2 (11b-HSD2) genotype, compared to hypertensive salt-resistant patients [67]. A synergistic effect between these 2 polymorphisms in relation to salt 
sensitivity was not present. The authors concluded that a polymorphism in these 2 genes (ACE I/D and 11b-HSD2) is significantly associated with salt-sensitive hypertension [67]. In a cross-sectional study of 284 Japanese working men (age range: 20-64 years) the interaction between the ACE I/D polymorphism and daily salt intake was examined [68]. ACE I/D per se was not associated with blood pressure levels or hypertension. ACE I/D interacted with daily salt intake and correlated with hypertension, suggesting a gene-environment interaction [68]. It is interesting to note that the genes which are overexpressed in the cerebral arteries following salt-induced hypertension are regulated by angiotensin II [69].

Some ethnic populations have been shown to have a greater incidence of hypertension compared with others. African-Americans are more prone to hypertension than Caucasians [70, 71]. The African-American RAS is more salt-sensitive and they tend to develop hypertension even with less sodium intake [72-74]. Changes in the local RAS have also been observed by a number of researchers in different tissues of various rat strains. Strehlow et al. [75] detected downregulation of aortic $\mathrm{AT}_{1}$ receptor density and aortic and renal $\left(\mathrm{AT}_{1}\right)$ receptor mRNA in Dahl salt-sensitive rats on a high-salt diet, whereas $\left(\mathrm{AT}_{1}\right)$ receptor mRNA was upregulated in the brain. Wang and $\mathrm{Du}$ [76] found increased $\left(\mathrm{AT}_{1}\right) \mathrm{mRNA}$ levels both in the aorta and in mesenteric resistance arteries of Wistar rats fed a high-salt diet. Stewen et al. [77] showed that $\left(\mathrm{AT}_{1}\right)$ receptor density was increased in the renal cortex of spontaneously hypertensive rats after chronic high salt intake. Bayorh et al. [78] evaluated changes in plasma and tissue levels of aldosterone and angiotensin II in Dahl salt-sensitive rats on a high-salt diet, as well as the reduced-tooxidized glutathione ratio. The high-salt diet caused a reduction in both plasma angiotensin II and aldosterone levels, while their levels in the heart and kidney were increased and the reduced-to-oxidized glutathione ratio in plasma, heart and kidney was lowered by exposure to high salt [78]. The authors concluded that high dietary salt induces inappropriate activation of the local reninangiotensin-aldosterone systems, that tissue levels of angiotensin II and aldosterone may be more reflective of the severity of vascular maladaptations than plasma levels are, and that they may play a greater role in the maintenance of hypertension [78].

There are important regulatory interactions between RAS, nitric oxide (NO) and $\mathrm{O}_{2}^{-}$in the kidney, where $\mathrm{O}_{2}^{-}$ acts as vasoconstrictor and enhances tubular sodium reabsorption and $\mathrm{NO}$ exhibits opposite effects. $\mathrm{O}_{2}^{-}$rapidly interacts with $\mathrm{NO}$ and thus, when $\mathrm{O}_{2}^{-}$production increas- es, it diminishes the bioavailability of NO leading to the impairment of organ function. At the same time, the activation of RAS can induce both $\mathrm{O}_{2}^{-}$and NO production [79]. It has been suggested that a balanced interaction between RAS, $\mathrm{NO}$ and $\mathrm{O}_{2}^{-}$provides a coordinated regulation of kidney function, whereas imbalance is linked to the pathophysiology of salt sensitivity and hypertension [79]. There were some interesting observations with the transgenic rat model of angiotensin II-dependent hypertension with constitutive mouse renin gene expression (TGR), which exhibits increased circulating and tissue angiotensin II levels and oxidative stress [79]. The highsalt diet induced increases in blood pressure in these animals, when compared to normal-salt diet age-matched TGR [80], with salt-sensitive responses in early stages of hypertension more pronounced in females, whereas salt restriction resulted in lower progression of hypertension in both males and females. These observations cannot be explained only by unresponsiveness of RAS activity to various levels of salt intake and, therefore, other unknown mechanisms need to be considered [79, 81].

\section{Endothelial Dysfunction May Play an Important Role in the Development of Hypertension}

Despite efforts devoted to elucidate the role of dietary salt intake in the development (and maintenance) of hypertension, the underlying mechanisms of salt loading that lead to impairment of endothelial function in saltsensitive hypertension have not been identified. However, there is an increasing body of evidence that normal regulation of the RAS plays an important role in the vascular relaxation mechanisms that are impaired in hypertension, and could contribute to maintenance of the high blood pressure by an elevated total peripheral resistance. Salt-sensitive patients display baseline RAS suppression and a blunted RAS response to high salt intake, which is inversely correlated with the BP response $[67,82]$. Panza et al. [83-85] reported a defect in the endothelium-derived $\mathrm{NO}$ system in patients with essential hypertension, which may account for increased vascular resistance under basal conditions and an impaired response to endothelium-dependent vasodilators. In a similar fashion, a later study by Bragulat et al. [86] demonstrated the involvement of the NO system in the pathogenesis of saltsensitive hypertension. That study showed a greater impairment of ACh-induced vasodilation and a significantly reduced effect of L-NMMA on vasodilation in salt-sensitive essential hypertensive patients compared to 
salt-resistant hypertensive patients. Maximal ACh-induced dilation was inversely correlated with the 24-hour mean blood pressure elevation during the high-salt diet, and 24-hour urinary secretion of nitrates was significantly decreased only in salt-sensitive patients [86]. Raij and coworkers showed, through multiple studies [87-89], that in salt-sensitive hypertensive rats there is a link between tissue angiotensin II, increased reactive oxygen species production, decreased NO bioactivity, and impaired endothelium-dependent relaxation to ACh.

On the other hand, other authors have failed to demonstrate the influence of increased dietary salt intake on NO-dependent vascular endothelial function. For example, forearm blood flow in response to ACh did not differ significantly between salt-sensitive and salt-resistant patients [90]. A study by Dishy et al. [91] on normotensive human subjects has shown that a high-salt diet leads to a significant decrease in the level of NO degradation products (nitrite and nitrate). Although blood pressure significantly increased with salt loading, changes in blood pressure from a low- to high-salt diet did not correlate with changes in plasma nitrite and nitrate. Additionally, forearm blood flow in response to mental stress (a mathematical task, which has been shown to be an NO-mediated vascular response) significantly increased from control levels in subjects on a high-salt diet, but was not significantly different compared to subjects on a low-salt diet [91]. The authors concluded that the increased blood pressure response to salt loading may occur through mechanisms other than changes in NO, or that salt-sensitive individuals are more sensitive to the reduced $\mathrm{NO}$ production that occurs after salt loading in both salt-sensitive and salt-resistant subjects [91]. More research needs to be done to resolve this question.

dos Santos et al. [92] found evidence of endothelial modulation in their experiments on isolated rat caudal and renal vascular beds. Salt treatment of healthy Wistar rats over 4 weeks increased systolic, diastolic and mean arterial pressures and sodium excretion in the absence of changes in plasma sodium levels. Salt increased the reactivity to phenylephrine (PHE) without changing the sensitivity to PHE in the tail vascular bed, but these parameters did not change in the renal bed [92]. In subsequent studies on the isolated caudal vascular bed, the authors found that endothelial damage, but not L-NAME or indomethacin, abolished the increment in PHE reactivity induced by high salt intake, whereas losartan reduced the reactivity in the high-salt diet group to control values [92]. Additionally, local ACE activity in segments from the tail artery increased by $95 \%$. Those studies indicate that 4 weeks of a high-salt diet induces specific territorial vascular changes in response to PHE. The authors also suggested that the increment in the vascular reactivity of the tail vascular bed was endothelium-dependent and was mediated by the activation of the local RAS [92].

\section{Animal Models of Hypertension}

Studies on animal models of hypertension have been more successful in demonstrating a genetic basis for saltsensitive hypertension. Genetic linkage analysis has revealed cosegregation of the SHR ('spontaneously hypertensive rats') renin allele with higher blood pressure and lower plasma renin concentrations in an F2 generation from an intercross of SHR and WKY (Wistar-Kyoto) rats [93] and salt-sensitive and Dahl $\mathrm{R}$ rats [94], but further genetic analysis of the polymorphism in the saltsensitive/R strains has not been pursued. A difference in nucleotide sequence was observed in the renin gene promoter region of SHR and WKY rats, and the target region showed protein binding [95]. Furthermore, unique nucleotide variations in intron I of the renin gene, the putative transcriptional factor binding site, were found in the SHR strain. It is possible that an alteration in the DNA binding characteristics that results in renin gene overexpression might form the basis for a tissue reninangiotensin-dependent form of hypertension in this strain of rats [96].

Different strains of rats may exhibit substantial differences in vascular control mechanisms and other physiological phenotypes, emphasizing the importance of understanding the role of genetic factors in determining physiological control mechanisms [97]. For example, the Dahl salt-sensitive rat strain represents an excellent model in which to study the importance of the RAS in the regulation of the mechanisms that mediate vascular reactivity. Salt-sensitive rats show impaired regulation of the RAS resulting in chronic, low levels of angiotensin II, which could be expected to lead to impaired relaxation to vasodilator stimuli. This rat strain exhibits many of the abnormalities, including salt sensitivity of blood pressure, that occur with hypertension in African-Americans, who exhibit a low-renin salt-sensitive form of hypertension, insulin-resistance and hyperlipidemia [98]. While salt-sensitive rats have low renin levels and high sodium intake suppresses plasma angiotensin II, kidney angiotensin II levels are not decreased by high salt. In fact, a high-salt diet increases renal angiotensinogen levels in salt-sensitive rats - a paradoxical enhancement 
which may represent an important contribution to salt sensitivity in this model [79].

Designer rat strains, such as congenic and consomic strains, provide a powerful strategy for mapping important functional traits and provide clues for genomic regions important in hypertension and in other complex traits. One component of the Programs for Genomic Applications project at the Medical College of Wisconsin utilizes the salt-sensitive rat strain together with the $\mathrm{BN}$ strain as parental strains to develop a panel of consomic rat strains that have individual chromosomes from the $\mathrm{BN}$ rat introgressed into the salt-sensitive genetic background by backcrossing. Those consomic rat strains provide a unique model to study the genetic basis of different cardiovascular traits, including blood pressure regulation $[99,100]$.

In their research related to the role of the renin gene in salt-dependent hypertension, Drenjancevic-Peric and colleagues [101-104] used 4 genetically inbred rat strains to explore the role of the RAS in regulating normal vascular relaxation mechanisms. The results of their studies showed that rats fed a high-salt diet have impaired vascular relaxation mechanisms and that introduction of a functioning renin gene by chromosomal transfer contributes to recovery of dilator responses [101]. These changes in vascular reactivity are found in the middle cerebral artery and mesenteric and skeletal muscle resistance arteries of the rat [101-105]. Other studies suggest that a high-salt diet leads to increased oxidative stress in the microcirculation and to altered ratios between pro- and antioxidative enzyme levels [106, 107]. It has been shown that the loss of vascular relaxation, impaired endothelial cell $\left(\mathrm{Ca}^{2+}\right)$ signaling, increased vascular oxidative stress, and reduced expression of $\mathrm{Cu} / \mathrm{Zn}$ superoxide dismutase in resistance arteries of animals fed a high-salt diet can all be prevented by chronic intravenous infusion of a subpressor dose of angiotensin II that prevents salt-induced angiotensin II suppression $[105,108]$. Not only angiotensin II suppression but also reduced interaction of angiotensin II with its $\mathrm{AT}_{1}$ receptor contributes to impaired vascular relaxation in Sprague-Dawley rats fed a high-salt diet [109111], which taken together with the other findings suggests that tonic activation of the $\mathrm{AT}_{1}$ receptor by normal circulating levels of angiotensin II plays an important role in maintaining vascular relaxation mechanisms under normal physiological conditions [105].

Some experiments have linked a high-salt diet to oxidative stress in the rostral ventrolateral medulla of spontaneously hypertensive rats [112], an area that contributes to the neural mechanisms involved in the development of hypertension. In those animals, elevated salt intake enhanced the blood pressure increase and sympathetic nervous system activity. Elevated dietary salt intake also enhances the sympathoexcitatory actions of angiotensin II in the rostral ventrolateral medulla via changes in the intrinsic properties of rostral ventrolateral medulla neurons [113].

The deoxycorticosterone acetate (DOCA)-salt hypertension model is interesting and might prove helpful in understanding the causes of hypertension resulting from hypervolemia, hyperaldosteronism and high salt intake. In the DOCA-salt rat model, the effects of chronic administration of DOCA (a mineralocorticoid) reduce renal mass and a high-salt diet leads to development of hypertension in several stages [114]. In the first $48 \mathrm{~h}$, there is an abrupt increase in arterial pressure, followed by a delayed, slower rise in arterial pressure over the next few weeks, leading to sustained hypertension. 8-12 weeks later, severe hypertension may be observed (malignant phase) [114]. Neural and humoral contributions might, alongside the dietary and renal factors, be important in the development of hypertension in this model, with neural factors (sympathetic nerve activity, possibly enhanced by increased sodium levels) contributing more in the early phases, and humoral factors (vasopressin and endothelin) contributing in the later malignant phase [114].

Salt-dependent increases in blood pressure have been found in other animal species as well. For example, Denton et al. [115] studied the effect of different sodium intake levels on blood pressure in chimpanzees. The effect of high salt intake differed between chimpanzees, with some animals having a large blood pressure rise and others a small rise or none at all. Overall, the authors found that sodium reduction can lower blood pressure and sodium addition can produce a significant elevation in arterial pressure [115].

\section{Possible Role of Renal Cytokine Gene Expression in the Development of Hypertension}

Cytokines, such as transforming growth factor-beta (TGF- $\beta$ )-1 (which is a modulator of multiple processes such as cell growth and proliferation, inflammation, endothelial and vascular smooth muscle cell function, and extracellular matrix metabolism), may play a role in human hypertension [116]. TGF- $\beta-1$ is involved in renal glomerulosclerosis, tubulointerstitial fibrosis and progressive renal failure, while studies in patients with essential hypertension linked circulating TGF- $\beta-1$ levels and mi- 
croalbuminuria [116]. Overexpression of TGF- $\beta$ by intravenous injection, transient gene transfer or transgene insertion in animals has shown that the kidney is highly susceptible to rapid fibrosis, and complex interactions between TGF- $\beta$ and the RAS have been discovered [117]. In various experiments on animals, such as in angiotensin II-induced hypertension, inflammatory changes associated with renal injury have been characterized and angiotensin II was proposed as the major factor responsible for monocyte recruitment and vascular inflammatory changes in the kidney [118, 119]. Other studies investigated renal inflammatory response in aldosterone/saltinduced hypertension and found that aldosterone/saltinduced renal vascular injury and fibrosis are associated with leukocyte infiltration and increased expression of the proinflammatory cytokines osteopontin, monocyte chemoattractant protein-1, interleukin-1 beta (IL-1 $\beta$ ) and IL-6 [118]. The inhibition of tumor necrosis factoralpha (TNF- $\alpha$ ) reduces renal injury in DOCA-salt hypertensive rats, suggesting a TNF- $\alpha$ contribution to the increase in renal inflammation [120]. Interestingly, the anti-inflammatory cytokine IL-10 has been demonstrated to have a significant antihypertensive effect. Adeno-associated virus vector-mediated systemic IL-10 expression reduces systolic blood pressure in Dahl salt-sensitive rats and potentially ameliorates hypertensive organ damage (including the kidneys) [121]. Although our knowledge about the role of changes in renal cytokine gene expression in the development of hypertension is still incomplete, it seems that these changes may be indeed relevant for a better understanding of the interaction of salt and the RAS in hypertension.

\section{Final Remarks}

The causes of essential hypertension are still unknown despite the investigative efforts of scientists worldwide. Taken together, the results of previous studies suggest that mutations in the renin gene (or other genes that encode components of the RAS) could be crucial in the development of hypertension and salt sensitivity. Besides the mentioned effects of high sodium intake on the RAS, endothelial dysfunction and sympathetic nervous system activity, there are other factors that cannot be disregarded as important contributors to the blood pressure increase linked to salt intake, including volume expansion (and elevated peripheral resistance in the later phase), functional changes of ion exchangers (such as the Na-Li countertransport), a polymorphism in the protein $\alpha$-adducin (the Gly460Trp allele) [122] and possibly a reduced activity of the kallikrein-kinin system in the kidney as recently proposed by Katori and Majima [122]. Better understanding of the mechanisms involved in the interaction of sodium intake and blood pressure will be essential for successful therapeutic interventions; and new insights into this issue represent a valuable means of controlling the aforementioned public health problems. But whatever the precise mechanisms may be, we can now say with nearly complete certainty that nonpharmacological treatment of the prehypertensive population, such as reduction in the salt intake, is crucial for reducing the number of hypertensive patients in the future. Public health measures should be directed toward increasing public awareness of the pathophysiological effects of excessive usage of dietary salt in the development of hypertension.

\section{References}

1 Mancia G, de Backer G, Dominiczak A, Cifkova R, Fagard R, Germano G, Grassi G, Heagerty AM, Kjeldsen SE, Laurent S, Narkiewicz K, Ruilope L, Rynkiewicz A, Schmieder RE, Boudier HA, Zanchetti A, Vahanian A, Camm J, De Caterina R, Dean V, Dickstein K, Filippatos G, Funck-Brentano C, Hellemans I, Kristensen SD, McGregor K, Sechtem U, Silber S, Tendera M, Widimsky P, Zamorano JL, Erdine S, Kiowski W, Agabiti-Rosei E, Ambrosioni E, Lindholm LH, Viigimaa M, Adamopoulos S, Agabiti-Rosei E, Ambrosioni E, Bertomeu V, Clement D, Erdine S, Farsang C, Gaita D, Lip G, Mallion JM, Manolis AJ, Nilsson PM, O’Brien E, Ponikowski P, Redon J, Ruschitzka F, Tamargo J, van Zwieten P, Waeber B, Williams B: 2007 Guidelines for the man- agement of arterial hypertension: the Task Force for the Management of Arterial Hypertension of the European Society of Hypertension (ESH) and of the European Society of Cardiology (ESC). J Hypertens 2007; 25:1105-1187.

2 World Health Organization: Fact Sheet: The Top Ten Causes Of Death. Fact sheet No. 310. Geneva, WHO, 2008.

3 World Health Organization: The World Health Report 2002: Reducing Risks, Promoting Healthy Life. Geneva, WHO, 2002.

4 Murray CJL, Lopez AD: Global mortality, disability, and the contribution of risk factors: Global Burden of Disease Study. Lancet 1997;349:1436-1442.
5 Kearney PM, Whelton M, Reynolds K, Muntner P, Whelton PK, He J: Global burden of hypertension: analysis of worldwide data. Lancet 2005;365:217-223.

-6 Lewington S, Clarke R, Qizilbash N, Peto R, Collins R, Prospective Studies Collaboration: Age-specific relevance of usual blood pressure to vascular mortality: a meta-analysis of individual data for one million adults in 61 prospective studies. Lancet 2002;360: 1903-1913.

>7 Vasan RS, Larson MG, Leip EP, Evans JC, O’Donnell CJ, Kannel WB, Levy D: Impact of high normal blood pressure on the risk of cardiovascular disease. N Engl J Med 2001; 345:1291-1297. 
8 Wolf-Maier K, Cooper RJS, Banegas JR, Giampaoli S, Hense H-W, Joffres M, Kastarinen M, Poulter N, Primatesta P, Rodríguez-Artalejo F, Stegmayr B, Thamm M, Tuomilehto J, Vanuzzo D, Vescio F: Hypertension prevalence and blood pressure levels in 6 European countries, Canada and the United States. JAMA 2003;289:2363-2369.

-9 Fields LE, Burt VL, Cutler JA, Hughes J, Roccella EJ, Sorlies P: The burden of adult hypertension in the United States 1999 to 2000. A rising tide. Hypertension 2004;44:398-404.

$\checkmark 10$ Fuentes R, Ilmaniemi N, Laurikainen E, Tuomilehto J, Nissinen A: Hypertension in developing economies: a review of population-based studies carried out from 1980 to 1998. J Hypertens 2000; 18:521-529.

- 11 Jelaković B, Zeljković-Vrkić T, Pećin I, Dika Z, Jovanović A, Podobnik D, Smuc T, Gamberger D, Katić K, Kasner M, Kuzmanić D: Arterial hypertension in Croatia. Results of EH-UH study. Acta Med Croatica 2007;61: 287-292.

-12 Zdrojewski T, Szpakowski P, Bandosz P, Pajak A, Wiszcek A, Krupa-Wojciechowska, Wyrzykowski B: Arterial hypertension in Poland in 2002. J Hum Hypertension 2004; 18:557-562.

$\checkmark 13$ Primatesta P, Poulter NR: Improvement in hypertension management in England: results from the Health Survey for England 2003. J Hypertens 2006;24:1187-1192.

14 Giampaoli S, Palmieri L, Dima F, Pilotto L, Vescio MF, Vanuzzo D: Socioeconomic aspects and cardiovascular risk factors: experience at the Cardiovascular Epidemiologic Observatory. Ital Heart J 2001;2:294-302.

-15 Banages JR, Rodriguez-Artalejo F, de la Cruz Trosca JJ, Guallar-Castillo P, del Rey Calero $\mathrm{J}$ : Blood pressure in Spain. Distribution, awareness, control and benefits of a reduction in average pressure. Hypertension 1998; 32:998-1002.

16 Thamm M: Blood pressure in Germany: current status and trends. Gesundheitswesen 1999;61:S90-S93.

-17 Stegmayr B, Harmsen P, Rajakangas A, Rastenyte D, Sarti C, Thorvaldsen P, Tuomilehto J: Stroke around the Baltic Sea: incidence, case fatality and population risk factors in Denmark, Finland, Sweden, and Lithuania. Cerebrovasc Dis 1996;6:80-88.

- 18 Kastarinen M, Antikainen R, Peltonen M, Laatikainen T, Barengo NC, Jula A, Salomaa V, Jousilahti P, Nissinen A, Vartiainen E, Tuomilehto J: Prevalence, awareness and treatment of hypertension in Finland during 1982-2007. J Hypertens 2009;27:1552-1559.

- 19 Zdrojewski T, Pienkowski R, Szynkiewicz M, Krupa-Wojcjechowska B: Have rapid socioeconomic changes influenced awareness of blood pressure in Poland? J Hum Hypertension 2001; 15:247-253.

-20 Asmar R, Vol S, Pannier B, Brisac AM, Tichet J, El Hasnaoui A: High blood pressure and associated cardiovascular risk factors in France. J Hypertens 2001;19:1727-1732.
21 Cifkova R, Škodova Z, Lanska V, Adamkova V, Novozamska E, Petržlikova Z, Jozífová $M$, Plásková M, Hejl Z, Palous D, Galovcová M: Trends in blood pressure levels, prevalence, awareness, treatment, and control of hypertension in the Czech population from 1985 to 2000/01. J Hypertens 2004;22:1479-1485.

22 Riecansky I, Egnerova A: Cardiovascular program in Slovakia. Results achieved over the years 1978-1989. Bratisl Lek Listy 1991; 92:203-218.

23 Dorobantu M, Bădilă E, Ghiorghe S, Darabont RO, Olteanu M, Flondor P: Total cardiovascular risk estimation in Romania. Data from the SEPHAR study. Rom J Intern Med 2008;46:29-37.

$\checkmark 24$ Guyton AC, Coleman TG, Cowley AW, Scheel KW, Manning RD, Norman RA: Arterial pressure regulation: overriding dominance of the kidneys in long-term regulation and in hypertension. Am J Med 1972;52: 584-594.

25 Guyton AC: Blood pressure control: special role of the kidneys and body fluids. Science 1991;252:1813-1816.

26 Rodriguez-Iturbe B, Vaziri ND: Salt-sensitive hypertension - update on novel findings. Nephrol Dial Transplant 2007;22:992995.

27 Julius S: Transition from high cardiac output to elevated vascular resistance in hypertension. Am Heart J 1988;116:600-606.

$28 \mathrm{Gu}$ JW, Anand V, Shek EW, Moore MC, Brady AL, Kelly WC, Adair TH: Sodium induces hypertrophy of cultured myocardial myoblasts and vascular smooth muscle cells. Hypertension 1998;31:1083-1087.

29 Gu JW, Tian N, Shparago M, Tan W, Bailey AP, Manning RD Jr: Renal NF-kappaB activation and TNF-alpha upregulation correlate with salt-sensitive hypertension in Dahl salt-sensitive rats. Am J Physiol Regul Integr Comp Physiol 2006;291:R1817-R1824.

30 Gu JW, Young E, Pan ZJ, Tucker KB, Shparago $M$, Huang $M$, Bailey $A P$ : Long-term high salt diet causes hypertension and alters renal cytokine gene expression profiles in Sprague-Dawley rats. Beijing Da Xue Xue Bao 2009;41:505-515.

- 31 Gu JW, Bailey AP, Tan W, Shparago M, Young E: Long-term high salt diet causes hypertension and decreases renal expression of vascular endothelial growth factor in Sprague-Dawley rats. J Am Soc Hypertens 2008;2:275-285.

$32 \mathrm{Gu} J W$, Manning RD Jr, Young E, Shparago M, Sartin B, Bailey AP: Vascular endothelial growth factor receptor inhibitor enhances dietary salt-induced hypertension in Sprague-Dawley rats. Am J Physiol Regul Integr Comp Physiol 2009;297:R142-R148.
33 James G, Baker T: Human population biology and blood pressure: evolutionary and ecological consideration and interpretations of population studies; in Laragh $\mathrm{JH}$, Brenner BM (eds): Hypertension, Diagnosis and Management, ed 2. New York, Raven Press, 1995, pp 115-135.

34 Carvalho J, Baruzzi R, Howard P, Poulter P, Alpers M, Franco LJ, Marcopito LF, Spooner VJ, Dyer AR, Elliott P: Blood pressure in four remote populations in the Intersalt study. Hypertension 1989;14:238-246.

35 Weinberger MH: Salt sensitivity of blood pressure in humans. Hypertension 1996;27: 481-490.

36 Intersalt: an international study of electrolyte excretion and blood pressure. Results for $24 \mathrm{~h}$ urinary sodium and potassium excretion. Intersalt Cooperative Research Group. BMJ 1988;297:319-328.

37 Cutler JA, Follmann D, Allender PS: Randomized trials of sodium reduction: an overview. Am J Clin Nutr 1997;65(Suppl 2):643S651S.

-38 Kempner W: Treatment of hypertensive vascular disease with rice diet. Am J Med 1948; 4:545-577.

-39 Sacks F, Svetkey L, Vollmer W, Appel L, Bray G, Harsha D, Obarzanek E, Conlin PR, Miller ER 3rd, Simons-Morton DG, Karanja N, Lin PH: Effects on blood pressure of reduced dietary sodium and the dietary approaches to stop hypertension (DASH) diet. N Engl J Med 2001;344:3-10.

40 He J, Ogden L, Vupputuri S, Bazzano L, Loria C, Whelton P: Dietary sodium intake and subsequent risk of cardiovascular disease in overweight adults. J Am Med Assoc 1999; 282:2027-2034

41 Hajjar I, Grim C, George V, Kotchen T: Impact of diet on blood pressure and age-related changes in blood pressure in the US population. Analysis of NHANES III. Arch Intern Med 2001;161:589-593.

42 Appel L, Espeland M, Easter L, Wilson A, Folmar S, Lacy C: Effects of reduced sodium intake on hypertension control in older individuals. Results from the Trial of Nonpharmacological Interventions in the Elderly (TONE). Arch Intern Med 2001; 161:685-693.

43 Kojuri J, Rahimi R: Effect of 'no added salt diet' on blood pressure control and $24 \mathrm{~h}$ urinary sodium excretion in mild to moderate hypertension. BMC Cardiovasc Disord 2007; 7:34.

44 Dickinson HO, Mason JM, Nicolson DJ, Campbell F, Beyer FR, Cook SW, Williams B, Ford GA: Lifestyle interventions to reduce raised blood pressure: a systematic review of randomised controlled trials. J Hypertens 2006;24:215-233.

-45 Graudal NA, Galloe AM, Garred P: Effects of sodium restriction on blood pressure, renin, aldosterone, catecholamines, cholesterols, and triglyceride: a meta-analysis. JAMA 1998;279:1383-1391. 
46 He FJ, MacGregor GA: How far should salt intake be reduced? Hypertension 2003;42: 1093-1099.

47 Robertson JIJ: Dietary salt and hypertension: a scientific issue or a matter of faith? J Eval Clin Pract 2003;9:1-22.

-48 Australian National Health and Medical Research Council, Dietary Salt Study Management Committee: Effects of replacing sodium intake in subjects on a low sodium diet: crossover study. Clin Exp Hypertens 1989;A11:1011-1024.

49 Jürgens G, Graudal NA: Effects of low sodium diet versus high sodium diet on blood pressure, renin, aldosterone, catecholamines, cholesterols, and triglyceride. Cochrane Database Syst Rev 2004;(1):CD004022.

50 Cook NR, Cutler JA, Obarzanek E, Buring JE, Rexrode KM, Kumanyika SK, Appel LJ, Whelton PK: Long term effects of dietary sodium reduction on cardiovascular disease outcomes: observational follow-up of the trials of hypertension prevention (TOHP). BMJ 2007;334:885.

-51 Baudouin M, Meyer P, Worcel M: Specific binding of $3 \mathrm{H}$-angiotensin II in rabbit aorta. Biochem Biophys Res Commun 1971;42: 434-440.

52 Devynck MA, Pernollet MG, Meyer P, Fermandjian S, Fromageot P: Angiotensin receptors in smooth muscle cell membranes. Nat New Biol 1973;245:55-58.

53 Tigerstedt R, Bergman PG: Niere und Kreislauf. Skand Arch Physiol 1988;8:223.

54 Tobian L, Tomboulian A, Janecek J: The effect of high perfusion pressure on the granulation of juxtaglomerular cells in an isolated kidney. J Clin Invest 1959;38:605-610.

-55 Ohkubo H, Kageyama R, Ujihara M, Hirose T, Inayama S, Nakanishi S: Cloning and sequence analysis of cDNA for rat angiotensinogen. Proc Natl Acad Sci USA 1983;80:21962200 .

-56 Skeggs LT, Marsh WH, Kahn JR, Shumway NP: The existence of two forms of hypertension. J Exp Med 1954;99:275-282.

-57 Unger T, Stoppelhaar M: Rationale for double renin-angiotensin-aldosterone system blockade. Am J Cardiol 2007;100:25J-31J.

-58 van Esch JH, Oosterveer CR, Batenburg WW, van Veghel R, Jan Danser AH: Effects of angiotensin II and its metabolites in the rat coronary vascular bed: is angiotensin III the preferred ligand of the angiotensin AT2 receptor? Eur J Pharmacol 2008;588(23):286-293.

-59 Yang R, Smolders I, De Bundel D, Fouyn R, Halberg M, Demaegdt H, Vanderheyden P, Dupont AG: Brain and peripheral angiotensin II type 1 receptors mediate renal vasoconstrictor and blood pressure responses to angiotensin IV in the rat. J Hypertens 2008; 26:998-1007.

60 Danilczyk U, Penninger JM: Angiotensinconverting enzyme II in the heart and the kidney. Circulation Res 2006;98:463-471.
61 Williams GH, Hollenberg NK: Sodium-sensitive essential hypertension: emerging insights into an old entity. J Am Coll Nutr 1989; 8:490-494.

62 Franco V, Oparil S: Salt sensitivity, a determinant of blood pressure, cardiovascular disease and survival. J Am Coll Nutr 2006; 25(Suppl 3):247S-255S.

63 Weinberger MH, Miller JZ, Luft FC, Grim CE, Fineberg NS: Definitions and characteristics of sodium sensitivity and blood pressure resistance. Hypertension 1986;8:II127II134.

64 Schulman IH, Aranda P, Raij L, Veronesi M, Aranda FJ, Martin R: Surgical menopause increases salt sensitivity of blood pressure. Hypertension 2006;47:1168-1174.

65 Hasimu B, Nakayama T, Mizutani Y, Izumi Y, Asai S, Soma M, Kokubun S, Ozawa Y: Haplotype analysis of the human renin gene and essential hypertension. Hypertension 2003;41:308-312.

66 Giner V, Poch E, Bragulat E, Oriola J, Gonzalez D, Coca A, De la Sierra A: Renin-angiotensin system genetic polymorphisms and salt sensitivity in essential hypertension. Hypertension 2000;35:512-517.

67 Poch E, Gonzalez D, Giner V, Bragulat E, Coca A, de la Sierra A: Molecular basis of salt sensitivity in human hypertension. Evaluation of renin-angiotensin-aldosterone system gene polymorphisms. Hypertension 2001;38:1204-1209.

68 Zhang L, Miyaki K, Araki J, Song Y, Kimura $\mathrm{T}$, Omae $\mathrm{K}$, et al: Interaction of angiotensin I-converting enzyme insertion-deletion polymorphism and daily salt intake influences hypertension in Japanese men. Hypertens Res 2006;29:751-758.

69 Rose P, Bond J, Tighe S, Toth MJ, Wellman TL, Briso de Montiano EM, Lewinter MM Lounsbury KM: Genes overexpressed in cerebral arteries following salt-induced hypertensive disease are regulated by angiotensin II, JunB, and CREB. Am J Physiol Heart Circ Physiol 2008;294:H1075-H1085.

70 Weinberger MH: Racial differences in renal sodium excretion: relationship to hypertension. Am J Kidney Dis 1993;21(4 Suppl 1):4145 .

71 Hertz RP, Unger AN, Cornell JA, Saunders E: Racial disparities in hypertension prevalence, awareness, and management. Arch Intern Med 2005;165:2098-2104.

72 Luft FC, Miller JZ, Grim CE, Fineberg NS, Christian JC, Daugherty SA, Weinberger $\mathrm{MH}$ : Salt sensitivity and resistance of blood pressure. Age and race as factors in physiological responses. Hypertension 1991; 17(Suppl 1):I102-I108

73 Richardson AD, Piepho RW: Effect of race on hypertension and antihypertensive therapy. Int J Clin Pharmacol Ther 2000;38:75-79.

74 Jamerson KA: Rationale for angiotensin II receptor blockers in patients with low-renin hypertension. Am J Kidney Dis 2000;36(3 Suppl 1):S24-S30.
75 Strehlow K, Nickenig G, Roeling J, Wassmann S, Zolk O, Knorr A, Böhm M: AT(1) receptor regulation in salt-sensitive hypertension. Am J Physiol 1999;277:H1701H1707.

76 Wang DH, Du Y: Regulation of vascular type 1 angiotensin II receptor in hypertension and sodium loading: role of angiotensin II. J Hypertens 1998;16:467-475.

77 Stewen P, Mervaala E, Karppanen H, Nyman T, Saijonmaa O, Tikkanen I, Fyhrquist F: Sodium load increases renal angiotensin type 1 receptors and decreases bradykinin type 2 receptors. Hypertens Res 2003;26:583-589.

78 Bayorh MA, Ganafa AA, Emmett N, Socci RR, Eatman D, Fridie IL: Alterations in aldosterone and angiotensin II levels in salt-induced hypertension. Clin Exp Hypertens 2005;27:355-367.

79 Kopkan L, Cervenka L: Renal interactions of renin-angiotensin system, nitric oxide and superoxide anion: implications in the pathophysiology of salt-sensitivity and hypertension. Physiol Res 2009;58(Suppl 2):S55-S67.

-80 Husková Z, Kramer HJ, Vanourková Z, Cervenka $L$ : Effects of changes in sodium balance on plasma and kidney angiotensin II levels in anesthetized and conscious Ren-2 transgenic rats. J Hypertens 2006;24:517527.

81 Husková Z, Kramer H, Vanourková Z, Thumová M, Malý J, Opocenský M, Skaroupková P, Kolský A, Vernerová Z, Cervenka L: Effects of dietary salt load and salt depletion on the course of hypertension and angiotensin II levels in male and female heterozygous Ren-2 transgenic rats. Kidney Blood Press Res 2007;30:45-55.

-82 De La Sierra A, Lluch MM, Coca A, Aguilera MT, Giner V, Bragulat E, Urbano-Márquez A: Fluid, ionic and hormonal changes induced by high salt intake in salt-sensitive and salt-resistant hypertensive patients. Clin Sci 1996;91:155-161.

83 Panza JA, Casino PR, Kilcoyne CM, Quyyumi AA: Role of endothelium-derived nitric oxide in the abnormal endothelium-dependent vascular relaxation of patients with essential hypertension. Circulation 1993;87: 1468-1474.

-84 Panza JA, Casino PR, Badar DM, Quyyumi AA: Effect of increased availability of endothelium-derived nitric oxide precursor on endothelium-dependent vascular relaxation in normal subjects and in patients with essential hypertension. Circulation 1993;87: 1475-1481.

-85 Panza JA, Quyyumi AA, Callahan TS, Epstein SE: Effect of antihypertensive treatment on endothelium-dependent vascular relaxation in patients with essential hypertension. J Am Coll Cardiol 1993;21:11451151.

-86 Bragulat E, de la SA, Antonio MT, Coca A: Endothelial dysfunction in salt-sensitive essential hypertension. Hypertension 2001;37: 444-448. 
-87 Zhou MS, Adam AG, Jaimes EA, Raij L: In salt-sensitive hypertension, increased superoxide production is linked to functional upregulation of angiotensin II. Hypertension 2003;42:945-951.

$\checkmark 88$ Zhou MS, Hernandez Schulman I, Pagano PJ, Jaimes EA, Raij L: Reduced NAD(P)H oxidase in low renin hypertension: link among angiotensin II, atherogenesis, and blood pressure. Hypertension 2006;47:81-86.

89 Schulman IH, Zhou MS, Raij L: Interaction between nitric oxide and angiotensin II in the endothelium: role in atherosclerosis and hypertension. J Hypertens Suppl 2006; 24:S45-S50.

-90 Higashi Y, Sasaki S, Nakagawa K, Kimura M, Noma K, Sasaki S, Hara K, Matsuura H, Chayama K, Oshima T: Sodium chloride loading does not alter endothelium-dependent vasodilation of forearm vasculature in either salt-sensitive or salt-resistant patients with essential hypertension. Hypertens Res 2001;24:711-716.

-91 Dishy V, Sofowora GG, Imamura H, Nishimi Y, Xie HG, Wood AJ, Stein CM: Nitric oxide production decreases after salt loading but is not related to blood pressure changes or nitric oxide-mediated vascular responses. J Hypertens 2003;21:153-157.

92 dos Santos L, Gonçalves MV, Vassallo DV, Oliveira EM, Rossoni LV: Effects of high sodium intake diet on the vascular reactivity to phenylephrine on rat isolated caudal and renal vascular beds: endothelial modulation. Life Sci 2006;78:2272-2279.

$\checkmark 93 \mathrm{Yu} \mathrm{H}$, Di Nicolantonio R: Altered nuclear protein binding to the first intron of the renin gene of the spontaneously hypertensive rat. Clin Exp Hypertens 1998;20:817-832.

$\checkmark 94$ Rapp JP, Wang SM, Dene H: A genetic polymorphism in the renin gene of Dahl rats cosegregates with blood pressure. Science 1989;243:542-544.

$\checkmark 95$ Leckie BJ: Polymorphisms of the renin gene promoter in spontaneously hypertensive and Wistar-Kyoto rats. Clin Exp Pharmacol Physiol 2001;28:60-63.

$\checkmark 6$ Di Nicolantonio R, Lan L, Wilks A: Nucleotide variations in intron 1 of the renin gene of the spontaneously hypertensive rat. Clin Exp Hypertens 1998;20:27-40

$\checkmark 97$ Cowley AW Jr, Stoll M, Greene AS, Kaldunski ML, Roman RJ, Tonellato PJ, Schork NJ, Dumas P, Jacob HJ: Genetically defined risk of salt sensitivity in an intercross of Brown Norway and SS rats. Physiol Genomics 2000; 2:107-115.

$\checkmark 98$ Cowley AW Jr, Roman RJ, Kaldunski ML, Dumas P, Dickhout JG, Greene AS, Jacob HJ: Brown Norway chromosome 13 confers protection from high salt to consomic SS rat. Hypertension 2001;37:456-461.
-99 Roman RJ, Cowley AW Jr, Greene A, Kwitek AE, Tonellato PJ, Jacob HJ: Consomic rats for the identification of genes and pathways underlying cardiovascular disease. Cold Spring Harb Symp Quant Biol 2002;67: 309-315.

100 Cowley AW Jr, Liang M, Roman RJ, Greene AS, Jacob HJ: Consomic rat model systems for physiological genomics. Acta Physiol Scand 2004; 181:585-592.

101 Drenjancevic-Peric I, Frisbee JC, Lombard $\mathrm{JH}$ : Skeletal muscle arteriolar reactivity in SS.BN13 consomic rats and Dahl salt-sensitive rats. Hypertension 2003;41:1012-1015.

102 Drenjancevic-Peric I, Lombard JH: Introgression of chromosome 13 in Dahl saltsensitive genetic background restores cerebral vascular relaxation. Am J Physiol Heart Circ Physiol 2004;287:H957-H962.

103 Drenjancevic-Peric I, Greene AS, Kunert $\mathrm{MP}$, Lombard JH: Arteriolar responses to vasodilator stimuli and elevated $\mathrm{P}(\mathrm{O} 2)$ in renin congenic and Dahl salt-sensitive rats Microcirculation 2004;11:669-677.

104 Drenjancevic-Peric I, Phillips SA, Falck JR, Lombard JH: Restoration of normal vascular relaxation mechanisms in cerebral arteries by chromosomal substitution in consomic SS.13BN rats. Am J Physiol Heart Circ Physiol 2005;289:H188-H195.

105 Drenjancevic-Peric I, Weinberg BD, Greene AS, Lombard JH: Restoration of cerebral vascular relaxation in renin congenic rats by introgression of the Dahl $\mathrm{R}$ renin gene. Am J Hypertens 2010;23:243-248.

106 Lenda DM, Sauls BA, Boegehold MA: Reactive oxygen species may contribute to reduced endothelium-dependent dilation in rats fed high salt. Am J Physiol 2000; 279:H7-H14.

107 Lenda DM, Boegehold MA: Effect of a highsalt diet on oxidant enzyme activity in skeletal muscle microcirculation. Am J Physiol 2002;282:H395-H402.

108 Zhu J, Huang T, Lombard JH: Effect of high-salt diet on vascular relaxation and oxidative stress in mesenteric resistance arteries. J Vasc Res 2007;44:382-390.

109 Weber DS, Lombard JH: Elevated salt intake impairs dilation of rat skeletal muscle resistance arteries via ANG II suppression. Am J Physiol Heart Circ Physiol 2000; 278:H500-H506.

110 Weber DS, Lombard JH: Angiotensin II AT1 receptors preserve vasodilator reactivity in skeletal muscle resistance arteries. Am J Physiol Heart Circ Physiol 2001, 280:H2196-H2202.

111 Phillips SA, Lombard JH: Chronic At1 receptor blockade alters the mechanisms mediating hypoxic dilation in middle cerebral arteries. J Cardiovasc Pharmacol 2005;46: $706-712$.
112 Koga Y, Hirooka Y, Araki S, Nozoe M, Kishi T, Sunagawa K: High salt intake enhances blood pressure increase during development of hypertension via oxidative stress in rostral ventrolateral medulla of spontaneously hypertensive rats. Hypertens Res 2008;31:2075-2083.

113 Adams JM, McCarthy JJ, Stocker SD: Excess dietary salt alters angiotensinergic regulation of neurons in the rostral ventrolateral medulla. Hypertension 2008;52: 932-937.

114 Yemane H, Busauskas M, Burris SK, Knuepfer MM: Neurohumoral mechanisms in deoxycorticosterone acetate (DOCA)-salt hypertension in rats. Exp Physiol 2010;95:51-55.

115 Denton D, Weisinger R, Mundy NI, Wickings EJ, Dixson A, Moisson P, Moisson P, Pingard AM, Shade R, Carey D, Ardaillou $\mathrm{R}$ : The effect of increased salt intake on blood pressure of chimpanzees. Nat Med 1995;1:1009-1016.

>116 Dell’Omo G, Penno G, Pucci L, Lucchesi D, Del Prato S, Pedrinelli R: Lack of association between TGF-beta-1 genotypes and microalbuminuria in essential hypertensive men. Nephrol Dial Transplant 2009;24: 1864-1869.

$\checkmark 117$ Border WA, Noble NA: Interactions of transforming growth factor-beta and angiotensin II in renal fibrosis. Hypertension 1998;31:181-188.

-118 Blasi ER, Rocha R, Rudolph AE, Blomme EA, Polly ML, McMahon EG: Aldosterone/ salt induces renal inflammation and fibrosis in hypertensive rats. Kidney Int 2003;63: 1791-1800.

119 Luft FC: Transforming growth factor betaangiotensin II interaction: implications for cardiac and renal disease. J Mol Med 1999; 77:517-518.

120 Elmarakby AA, Quigley JE, Imig JD, Pollock JS, Pollock DM: TNF-alpha inhibition reduces renal injury in DOCA-salt hypertensive rats. Am J Physiol Regul Integr Comp Physiol 2008;294:R76-R83.

- 121 Nonaka-Sarukawa M, Okada T, Ito T, Yamamoto K, Yoshioka T, Nomoto T, Hojo Y, Shimpo M, Urabe M, Mizukami H, Kume A, Ikeda U, Shimada K, Ozawa K: Adeno-associated virus vector-mediated systemic interleukin-10 expression ameliorates hypertensive organ damage in Dahl salt-sensitive rats. J Gene Med 2008;10: 368-374.

122 Katori M, Majima M: A missing link between a high salt intake and blood pressure increase. J Pharmacol Sci 2006;100:370390 